\title{
The cell cycle related apoptotic susceptibility to arsenic trioxide is associated with the level of reactive oxygen species
}

\author{
Fei GAO ${ }^{1}$, Jing YI ${ }^{1}$, Jing Qi YUAN ${ }^{2}$, Gui Ying SHI ${ }^{1}$, Xue Ming TANG ${ }^{1, *}$ \\ ${ }^{1}$ Department of Cell Biology, Shanghai Second Medical University, Shanghai 200025, China. \\ ${ }^{2}$ Department of Automation, Shanghai Jiaotong University, Shanghai 200031, China.
}

\begin{abstract}
Double staining flow cytometry was performed using 7-amino actinomycin D and 6-carboxy-2',7'dichlorodihydrofluorescein diacetate, to detect the level fluctuation of reactive oxygen species (ROS) during the cell cycle of normal NB4 cells. Our results showed that NB4 cells possessed higher level of ROS in G2/M phase than in G1 and S phases. Double staining flow cytometry, with TdT mediated dUTP nick end labeling (Tunel) and propidium iodide (PI), indicated that $\mathrm{As}_{2} \mathrm{O}_{3}(2 \mu M)$ could induce apoptosis in NB4 cells prevailingly from G2/M phase, and this efficacy was enhanced upon co-administration of 2, 3-dimethoxy-1, 4-naphthoquinone (DMNQ) (2.5 $\mu M$ ) which could produce the endogenous ROS. These results suggested that different ROS level in different cell cycle phases of NB4 cells might determin the selective induction of G2/M apoptosis and the cells' susceptibility to apoptosis by $\mathrm{As}_{2} \mathrm{O}_{3}$.
\end{abstract}

Keywords: arsenic trioxide, apoptosis, cell cycle, reactive oxygen species (ROS).

\section{INTRODUCTION}

Arsenic trioxide $\left(\mathrm{As}_{2} \mathrm{O}_{3}\right)$ has been successfully introduced into clinic trial and thus approved by US Food and Drug Administration (FDA) for treatment of acute promyelocytic leukemia (APL) recently[1-6]. Although it has been widely accepted that, like $\mathrm{As}_{2} \mathrm{O}_{3}$, many chemotherapeutic drugs function as pro-apoptotic signals which can trigger apoptosis in tumor cells, the heterogeneity of cellular susceptibility to these cytotoxic agents limited their usage on more types of tumors in clinic[7-13].

Reactive oxygen species (ROS), including superoxide radical $\left(\mathrm{O}_{2} \cdot{ }^{-}\right)$, hydrogen peroxide $\left(\mathrm{H}_{2} \mathrm{O}_{2}\right)$, hydroxyl radical $(\mathrm{OH})$ and singlet oxygen $\left({ }^{1} \mathrm{O}_{2}\right)$, continuously generated from mitochondrial respiratory chain, have powerful oxidative potential, and are known to be capable of resulting in the oxidative damages. Cells possess an efficient antioxidant defense system, composed of mainly the enzymes such as superoxide dismutase, glutathione peroxidase, and catalase, which can scavenge the excessive ROS and keep its level relatively stable under physiological conditions[1416]. Recent data showed that many pro-apoptotic signals could raise the cellular ROS level, and celluar inherent ROS level may be associated with the susceptibility of tumor cells to pro-apoptotic signals[10-13, 17-29].

Some researchers reported that low concentration (1-2 $\mathrm{m} M$ ) of $\mathrm{As}_{2} \mathrm{O}_{3}$ preferentially induced apoptosis in NB4 cells

\footnotetext{
${ }^{*}$ Correspondence author: Xue Ming TANG

Tel: +86-21-63846590 (ext. 776480), Fax: +86-21-53065329,

E-mail: xmtang@shsmu.edu.cn
}

of G2/M phase [30]. Our recent work indicated that different susceptibility of cell lines to $\mathrm{As}_{2} \mathrm{O}_{3}$-induced apoptosis may possess different ROS levels, and thus suggested that inherent ROS level might be determinative in cellular apoptotic susceptibility to $\mathrm{As}_{2} \mathrm{O}_{3}[11]$. We therefore questioned whether there was a ROS level fluctuation in cell cycle duration, and cell cycle-related apoptosis of NB4 cells induced by $\mathrm{As}_{2} \mathrm{O}_{3}$ was associated with such a ROS level variation in cell cycle phases. We herein, first, using a flow cytometric double-staining method, detected the ROS levels in the respective phases of the normal cell cycle, and then investigated the relationship between the variation of ROS level during cell cycle and the apoptosis induced by $\mathrm{As}_{2} \mathrm{O}_{3}$ in NB4 cells.

\section{MATERIALS AND METHODS}

\section{Reagents}

$\mathrm{As}_{2} \mathrm{O}_{3}, 6$-carboxy-2',7'-dichlorodihydrofluorescein diacetate (DCFH-DA), 7-amino actinomycin D (7AAD), propidum iodide (PI) and N-Acetyl-cystein (NAC) were purchased from Sigma Chemical Co. (St Louis, MO, USA). 2,3-dimethoxy-1,4-naphthoquinone (DMNQ) was purchased from Calbiochem (San Diego, CA, USA). Catalase was purchased from Huamei Company (Luoyang, Henan, China). $\mathrm{As}_{2} \mathrm{O}_{3}$ was dissolved in small amounts of $1.0 \mathrm{M} \mathrm{NaOH}$, then diluted to $10.0 \mathrm{~m} M$ with phosphate-buffered saline (PBS) as stock solution.

\section{Cell culture}

Acute promylocytic leukemia cell line NB4, kindly supplied by Shanghai institute of hematology, was cultured in RPMI-1640 me- 
dium (GibcoBRL, Gaitherburg, MD, USA) supplemented with 100 $\mathrm{IU} / \mathrm{mL}$ pennicillin, $100 \mathrm{mg} / \mathrm{ml}$ streptomycin, and $10 \%$ fetal bovine serum(FBS; GibcoBRL) in a fully humidified atmosphere with 5\% $\mathrm{CO}_{2}$ at $37^{\circ} \mathrm{C}$. Cell culture was daily split and maintained at a density less than $5 \times 10^{5}$ cells $/ \mathrm{ml}$.

\section{ROS detection}

DCFH-DA was used for ROS detection. DCFH-DA is cleaved intracellularly by nonspecific esterases to form DCFH, which is further oxidized by ROS to form the fluorescent compound DCF [31]. DCFH-DA working solution was added directly to the medium to reach $10 \mu M$, and then incubated at $37^{\circ} \mathrm{C}$ for $15 \mathrm{~min}$. Cells were then washed once, resuspended in PBS and kept on ice for an immediate detection by FACScan (Becton Dickinson, USA). When determining the effects of drugs and antioxidants on ROS level, cells were exposed to antioxidants catalase or NAC for $2 \mathrm{~h}$ before drug treatment, and DCFH-DA staining was applied simultaneously with the drug exposure for $15 \mathrm{~min}$.

Double staining flow cytometry was performed, using 7AAD to display DNA content, and DCFH-DA to detect ROS, thus showing the level fluctuation of ROS during a normal cell cycle of NB4 cells free of pro-apoptotic treatment.. 7AAD was applied to measure DNA content in order to identify the cell cycle distribution[32]. NB4 cells were treated with $10 \mu M$ DCFH-DA for 10min in normal cultured conditions. After washing in PBS, cells were resuspended in 7AAD labeling buffer $(0.1 \mathrm{M}$ phosphate-citrate buffer containing 0 . $15 M \mathrm{NaCl}, 5 \mathrm{~m} M$ EDTA, $0.5 \% \mathrm{BSA}$ and $0.004 \%$ saponin, $\mathrm{pH} 6.0$ ) before 7AAD was added in a final concentration of $20 \mu M$ [32]. Cells were analyzed by FACScan (Becton Dickinson, USA) following 7AAD incubation for 5-7 min.

\section{Apoptosis and cell cycle analysis}

In order to visualize the apoptosis, NB4 cells were exposed to either $2 \mu \mathrm{MAs}_{2} \mathrm{O}_{3}$ alone or in combination with some ROS producer and inhibitors for 16 hours.

TdT-mediated dUTP nick-end labeling (Tunel) / propidium iodide (PI) double staining flow cytometry was performed, to assess the apoptotic rate and to know from which phase these apoptotic cells came. Cells were fixed with $4 \%$ paraformaldehyde for $30 \mathrm{~min}$ at room temperature. After washing twice with PBS, cells were resuspended with $70 \%$ pre-cold ethanol and immediately transferred into freezer. The samples were stored at $-20^{\circ} \mathrm{C}$ for overnight. Cells were then rehydrated by washing twice with PBS before resuspended in $50 \mathrm{~mL}$ Tunel reaction mixture (In Situ Cell death Detection Kit, Roche, Germany) and incubated for $60 \mathrm{~min}$ at $37^{\circ} \mathrm{C}$ in a humidified atmosphere in dark. After washed twice with PBS, cells were treated with $100 \mathrm{U} / \mathrm{ml}$ RNAse containing $0.002 \%$ TritonX 100 for $15 \mathrm{~min}$, and stained with PI (the final concentration $50 \mu \mathrm{g} / \mathrm{ml}$ ) for $20 \mathrm{~min}$ before analyzed by FACScan[30, 33].

\section{RESULTS}

\section{The ROS level varied during the normal cell cycle of NB4 cells}

During the single cell cycle, intracellular ROS levels of the intact NB4 cells increased significantly from G1, S phase, to G2/M phase (Fig 1).
$\mathrm{As}_{2} \mathrm{O}_{3}$ selectively induced apoptosis of NB4 cells phases from G2/M phase

Upon $2 \mu M \mathrm{As}_{2} \mathrm{O}_{3}$ administrtion for $16 \mathrm{~h}, \mathrm{NB} 4$ cells were selectively induced apoptosis from G2/M phase (Fig $2 \mathrm{~A}, \mathrm{~B})$.

\section{DMNQ enhanced the efficacy of $\mathrm{As}_{2} \mathrm{O}_{3}$ in ROS-de- pendant manner}

$2 \mu M \mathrm{As}_{2} \mathrm{O}_{3}$ in combination with $2.5 \mu M$ DMNQ (endogenous ROS producing reagent[34]) induced more cells to apoptosis from $\mathrm{G} 2 / \mathrm{M}$ phase than $\mathrm{As}_{2} \mathrm{O}_{3}$ alone (Fig 2C).

To know whether the effect of DMNQ on promoting $\mathrm{As}_{2} \mathrm{O}_{3}$-induced apoptosis was ROS-dependant, we investigated cellular ROS level upon DMNQ treatment alone or together with two types of antioxidants, or ROS inhibitors and scanvangers, catalase and NAC. The data showed that DMNQ did elevate the cellular ROS level and the treatment of catalase or NAC could revers it totally. Exposure to $\mathrm{As}_{2} \mathrm{O}_{3}$ alone also resulted in a ROS elevation, and this efficacy was strikingly enhanced by DMNQ cotreatment. Catalase or NAC had the capacity to reverse ROS level elevated by $\mathrm{As}_{2} \mathrm{O}_{3} /$ DMNQ combination (Fig 3).

Correspondingly, the proportion of apoptotic cells was closely associated with the cellular ROS level. DMNQ dramasticlly enhanced the efficacy of $\mathrm{As}_{2} \mathrm{O}_{3}$ on apoptosis induction of NB4 cells. Upon administration of $2 \mu M \mathrm{As}_{2} \mathrm{O}_{3}$ together with DMNQ and catalase(or NAC) treatment, the propotion of apoptotic cells was similar to that with $\mathrm{As}_{2} \mathrm{O}_{3}$ treatment alone(Fig 4). This showed that the apoptosisenhancing efficacy of DMNQ was reversed by catalase or NAC. Thus we came into a conclusion that the effect of DMNQ on promoting $\mathrm{As}_{2} \mathrm{O}_{3}$-induced apoptosis from $\mathrm{G} 2 / \mathrm{M}$ phase was ROS-dependant.

\section{DISCUSSION}

The previous studies indicated that the changes of ROS level might play a role in apoptosis induced by $\mathrm{As}_{2} \mathrm{O}_{3}[12$, 13]. Our recent work indicated that cell lines differently susceptible to $\mathrm{As}_{2} \mathrm{O}_{3}$-induced apoptosis possessed different ROS levels which might be determitive in their apoptotic susceptibility to $\mathrm{As}_{2} \mathrm{O}_{3}$. For instance, we manifested that, there was a inherently existed difference in whole ROS quantity among four kinds of leukemia cell lines NB4, HL60, K562 and U937, and a positive correlation between the inherent ROS level and their apoptotic sensitivity to $\mathrm{As}_{2} \mathrm{O}_{3}$. Furthermore, by interference using a ROS producer DMNQ, we demonstrated that an elevation of ROS level would sensitize the cells to $\mathrm{As}_{2} \mathrm{O}_{3}$-induced apoptosis[11].

In the present study our results showed that a low dose $(2 \mu M)$ of $\mathrm{As}_{2} \mathrm{O}_{3}$ induced the apoptosis of NB4 cells pre- 



Fig 1. 7AAD/DCFHDA double labeling flow cytometry displaying ROS level during a normal cell cycle. A. DNA histogram. B. 7AAD/DCFHDA bivariate dot-blots, R1: G1 phase, R2: S phase, R3: G2/M phase.

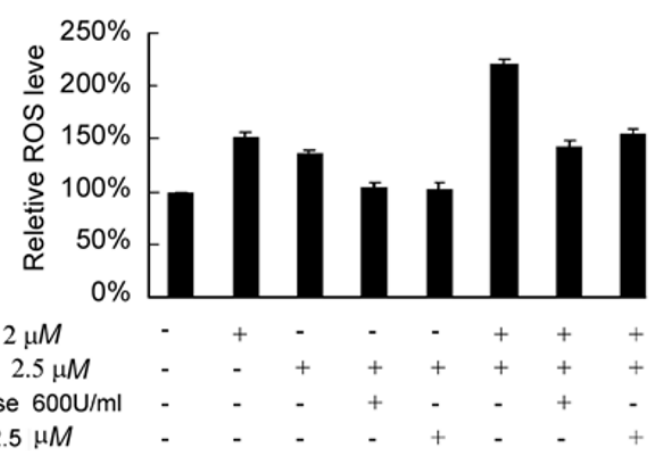

Fig 3. Effect of DMNQ on elevating ROS level determined by flow cytometry and represented by DCF fluorescence intensity (mean \pm $\mathrm{SD}, \mathrm{n}=3$ ). NB4 cells were treated with DMNQ alone or together with $A s_{2} \mathrm{O}_{3}$, catalase or NAC for $15 \mathrm{~min}$. (Catalase and NAC were pre-incubated with the cells for $2 \mathrm{~h}$.)

vailingly from $\mathrm{G} 2 / \mathrm{M}$ phase. This was coincident with other researcher's results[30].

To our knowledge, methodology applying 7AAD and DCFH-DA double staining flow cytometry had not been documented, even if 7AAD used in DNA measurement and DCFH-DA in ROS detection were separately established[31,32]. The feasibility of this novel approach was demonstrated in the present work. Our data showed that during a normal cell cycle in NB4 cells, ROS levels gradually increased from $\mathrm{G} 1, \mathrm{~S}$ to $\mathrm{G} 2 / \mathrm{M}$ phases, or alternatively speaking, G2/M phase cells possessed inherently greater content of ROS than G1 and S phase cells. The higher level of ROS in G2/M phase might be thus logically assumed to account for that $\mathrm{G} 2 / \mathrm{M}$ cells were more predisposed to apoptosis induction by $2 \mu M \mathrm{As}_{2} \mathrm{O}_{3}$.

The cell cycle related differences in susceptibility to apoptosis induced by various antitumor agents have been noticed for long in HL-60 cells[35], in which cells in G2/ $\mathrm{M}$ phase were largely apoptotic when treated with a serine/ threonine kinase inhibitor $\mathrm{H7}$ or with gamma-irradiation
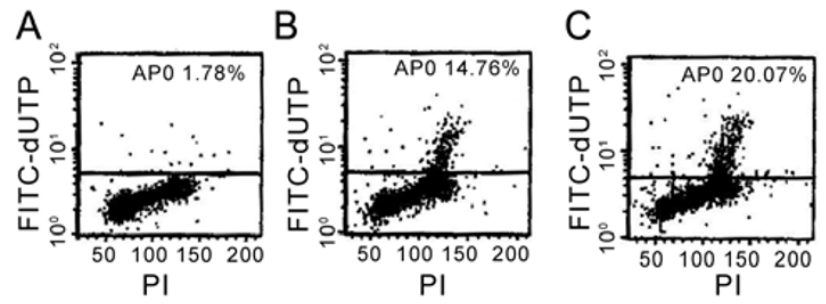

Fig 2. Tunel/PI bivariate dot-blots displaying prevailling apoptotic cells from $\mathrm{G} 2 / \mathrm{M}$ phase of NB4 cells upon administration of $\mathrm{As}_{2} \mathrm{O}_{3}$ at $2 \mu M$ alone or in combination with $2.5 \mu M$ DMNQ for $16 \mathrm{~h}$. A: control; $\mathrm{B}: \mathrm{As}_{2} \mathrm{O}_{3}$ alone; $\mathrm{C}: \mathrm{As}_{2} \mathrm{O}_{3}$ in combination with DMNQ.

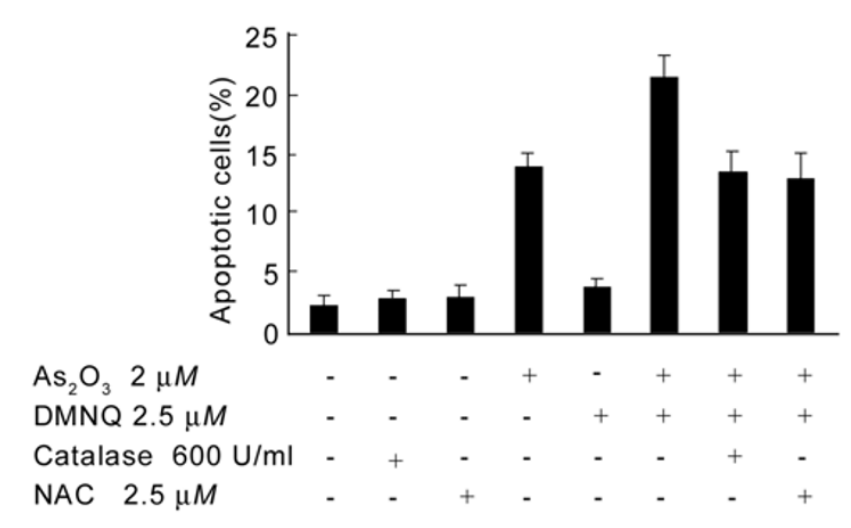

Fig 4. Apoptotic rates analyzed by Tunel/PI double labeling flow cytometry ( mean $\pm \mathrm{SD}, \mathrm{n}=3$ ). NB4 cells were treated with $\mathrm{As}_{2} \mathrm{O}_{3}$ alone or together with DMNQ, catalase or NAC for $16 \mathrm{~h}$.

whereas some other agents induced G1 or S phase cell apoptosis selectively. Though the clinic relevance of this mode of cell death was discussed, the mechanisms underlying cell cycle related differences in apoptosis susceptibility were virtually obscure[35]. B lymphocytes' growth arrest and apoptosis induced by activation displayed G1 phase specificity[36], and this was partially explained by the delicately regulated expression or posttranslation modification of cyclin-dependent kinase 2 and other cell cycle proteins. In the present study we found the link of ROS level variance in the cell cycle with the cycle-related apoptosis induced by $\mathrm{As}_{2} \mathrm{O}_{3}$. Since ROS has been considered as one of mediators of cell apoptosis induced by UV exposure and gamma-irradiation[37], and also by arsenic trioxide[10-13] in varied types of cell, the higher apoptosis susceptibility in G2/M phase to gamma-irradiation might be presumed to reflect a mechanism similar to one described here, in which ROS played a crucial role in determining the cell cycle related apoptosis susceptibility.

The link of ROS variance during the cell cycle with the 
apoptosis susceptibility might imply that there existed a "threshold level" for ROS, under which cell could survive its oxidative damages and apoptosis triggering. Thinking of that $\mathrm{As}_{2} \mathrm{O}_{3}$ could elevate the ROS level of NB4 cells, we deduce that, upon treatment with $\mathrm{As}_{2} \mathrm{O}_{3}$, the ROS level of $\mathrm{G} 2 / \mathrm{M}$ phase cells exceeded that cell could endure. Hence the cells in G2/M phase were induced to apoptosis after a transitory replication arrest. The ROS levels of G1 and S phases cells were still under the "threshold level" after treatment with $\mathrm{As}_{2} \mathrm{O}_{3}$. These cells could progress to next stage of cell cycle, but ultimately be arrested in G2/M phase and triggered to apoptosis as well.

To affirm the association of ROS variance in the cell cycle with apoptosis susceptibility, we use DMNQ in combination with $\mathrm{As}_{2} \mathrm{O}_{3}$ for apoptosis induction. DMNQ facilitated the efficacy of $\mathrm{As}_{2} \mathrm{O}_{3}$ on selective induction of apoptosis of NB4 cells from G2/M phase. This efficacy of DMNQ could be reversed by catalase and NAC. DMNQ, one type of quinones that underwent redox cycling and was widely used to investigate oxidative stress, has been proved to generate endogenous ROS and carried into execution of apoptosis through ROS-dependent pathway [34]. Since DMNQ produced ROS whereas catalase and NAC removed ROS from cells, our results further argued that ROS level difference in the respective cell cycle phases of NB4 cells should be pivotal in cycle-related cellular sensitivity to $\mathrm{As}_{2} \mathrm{O}_{3}$-induced apoptosis.

As some other investigators demonstrated that a high dose of $\mathrm{As}_{2} \mathrm{O}_{3}(8 \mu M)$ induced apoptosis of NB4 cells from each phase of cell cycle[30], and a very low dose of $\mathrm{As}_{2} \mathrm{O}_{3}$ (less than $0.5 \mu M$ ) didn't induce apoptosis at all[38], we made a systematic observation on the efficacy caused by different concentration of $\mathrm{As}_{2} \mathrm{O}_{3}(0.5-8 \mu M)$ and got the similar findings (data not shown). This phenomenon, as we assumed, might be attributed to ROS threshold hypothesis. ROS levels in each phase of NB4 cell cycle, upon $8 \mu M \mathrm{As}_{2} \mathrm{O}_{3}$ administration, might surpass the threshold and elicit an intensive apoptosis of cells in all phases, while ROS levels keep safe for the cells in all phases after administration with less than $0.5 \mu M \mathrm{As}_{2} \mathrm{O}_{3}$.

The results in the present study and the ROS threshold hypothesis we proposed based on them seemed to shed more lights on the mechanisms by which $\mathrm{As}_{2} \mathrm{O}_{3}$ induce apoptosis in certain types of tumor cells. Not only $\mathrm{As}_{2} \mathrm{O}_{3}$ induced apoptosis be ROS dependent, also ROS likely be of determination in cellular suceptibility to apoptosis induction by $\mathrm{As}_{2} \mathrm{O}_{3}$. As it has been clear that mitochondria is a central executor in apoptosis[39], it is conceivable to recognize the unique and pivotal role of ROS. Identification in detail how ROS mediates and signals $\mathrm{As}_{2} \mathrm{O}_{3}$ induce apoptosis will certainly help to elucidate the mechanisms of apoptosis induced by $\mathrm{As}_{2} \mathrm{O}_{3}$ and other chemotherapeutic agents.

Received, Dec 12, 2002

Revised, July 10, 2003

Accepted, Sep 7, 2003

\section{ACKNOWLEDGMENTS}

This project was supported by research grants from National Natural Science Foundation of China (No. 30170475).

\section{REFERENCES}

1 Shen ZX, Chen GQ, Ni JH, et al. Use of arsenic trioxide $\left(\mathrm{As}_{2} \mathrm{O}_{3}\right)$ in the treatment of acute promyelocytic leukemia (APL): II. Clinical efficacy and pharmacokinetics in relapsed patients. Blood 1997; 89:3354-60.

2 Soignet SL, Maslak P, Wang ZG, et al. Complete remission after treatment of acute promyelocytic leukemia with arsenic trioxide. N Engl J Med 1998; 339:1341-8.

3 Soignet SL, Frankel SR, Douer D, et al. United States multicenter study of arsenic trioxide in relapsed acute promyelocytic leukemia. J Clin Oncol 2001; 19(18):3852-60.

4 Wang ZY. Arsenic compounds as anticancer agents. Cancer Chemother Pharmacol 2001; 48 Suppl 1:S72-76.

5 Chen Z, Chen GQ, Shen ZX, et al. Expanding the use of arsenic trioxide: leukemias and beyond. Semin Hematol 2002; 39 (2 Suppl 1):22-6.

6 FDA approves arsenic trioxide for leukemia treatment in record time for a cancer drug development program. FDA talk paper T00-47, Sep $26^{\text {th }}, 2000$.

7 Hannun YA. Apoptosis and the Dilemma of Cancer Chemotherapy. Blood 1997; 89:1845-53.

8 Johnstone RW, Ruefli AA, Lowe SW. Apoptosis: a link between cancer genetics and chemotherapy. Cell 2002; 108(2):153-64.

9 Chu E, Devita VT. Principle of cancer management: chemotherapy. In chief-editor Devita VT, Hellman S and Roseberg SA. Cancer principle \& practice of oncology (6th edition). (USA) Philadelphia: Lippincott Williams \& wilkins Press 2001; 289-307.

10 Gao F, Yi J, Shi GY, Li H, Shi XG, Tang XM. The sensitivity of digestive tract tumor cells to $\mathrm{As}_{2} \mathrm{O}_{3}$ is associated with the inherent cellular level of reactive oxygen species. World J Gastroenterol 2002; 8(1):36-9.

11 Yi J, Gao F, Shi GY, et al. The inherent cellular level of reactive oxygen species: one of the mechanisms determining apoptotic susceptibility of leukemic cells to arsenic trioxide. Apoptosis 2002; 7(3):209-15.

12 Dai J, Weinberg RS, Waxman S, Jing YK Malignant cells can be sensitized to undergo growth inhibition and apoptosis by arsenic trioxide through modulation of the glutathione redox system. Blood 1999; 93:268-77.

13 Jing YK, Dai J, Chalmers-Redamn RE, Tatton WG, Waxman S. Arsenic trioxide selectively induces acute promyelocytic leukemia cell apoptosis via hydrogen peroxide-dependent pathway. Blood 1999; 94:2102-11.

14 Papa S and Skulachev V P. Reactive oxygen species, mitochondria, apoptosis and aging. Mol Cell Biochem 1997; 174:305-19. 
15 Chapple I L. Reactive oxygen species and antioxidants in inflammatory diseases. J Clin Periodontol 1997; 24:287-96.

16 Boss O, Hagen T, Lowell BB. Perspectives in diabetes. Uncoupling Protein 2 and 3 potential regulators of mitochondrial energymetabolism. Diabetes 2000; 49:143-56.

17 Carmody RJ, Cotter TG. Signalling apoptosis: a radical approach. Redox Rep 2001; 6(2):77-90.

18 Biroccio A, Benassi B, Amodei S, Gabellini C, Del Bufalo D, Zupi G. c-Myc down-regulation increases susceptibility to cisplatin through reactive oxygen species-mediated apoptosis in M14 human melanoma cells. Mol Pharmacol 2001; 60(1):17482.

19 Panaretakis T, Shabalina IG, Grander D, Shoshan MC, DePierre JW. Reactive oxygen species and mitochondria mediate the induction of apoptosis in human hepatoma HepG2 cells by the rodent peroxisome proliferator and hepatocarcinogen, perfluorooctanoic acid. Toxicol Appl Pharmacol 2001; 173(1): 56-64.

20 Osawa Y, Nagaki M, Banno Y, et al. Possible involvement of reactive oxygen species in D-galactosamine-induced sensitization against tumor necrosis factor-alpha-induced hepatocyte apoptosis. J Cell Physiol 2001; 187(3):374-85.

21 Bauer G. Reactive oxygen and nitrogen species: efficient, selective, and interactive signals during intercellular induction of apoptosis. Anticancer Res 2000; 20(6B):4115-39.

22 Mary-Quillet A, Jaffrezou J, Mansa V, Bordier C, Naval J, Laurent G. Implication of mitochondrial hydrogen peroxide generation in ceramide-induced apoptosis. J Biol Chem 1997; 272:2138895.

23 Manna SK, Zhang HJ, Yan T, Oberley LW, Aggarwal BB. Overexpression of manganese superoxide dismutase suppresses tumor necrosis factor-induced apoptosis and activation of nucjear transcription factor-kappaB and activated pretein-1. J Boil Chem 1998; 273:13245-54.

24 Provinciali M, Donnini A, Argentati K, Di Stasio G, Bartozzi B, Bernardini G. Reactive oxygen species modulate $\mathrm{Zn}^{2+}$-induced apoptosis in cancer cells. Free Radic Biol Med 2002; 32(5):431-45.

25 Chandel NS, Schumacker PT, Arch RH. Reactive oxygen species are downstream products of TRAF-mediated signal transduction. J Biol Chem 20016; 276(46):42728-36.

26 Isuzugawa $\mathrm{K}$, Inoue M, Ogihara Y. Catalase contents in cells determine sensitivity to the apoptosis inducer gallic acid. Biol Pharm Bull 2001; 24(9):1022-6.
27 Wang TS, Kuo CF, Jan KY, Huang H. Arsenite induces apoptosis in Chinese hamster ovary cells by generation of reactive oxygen species. J. Cell Physiol. 1996; 169:256-68.

28 Chen YC, Lin-Shiau SY Lin JK, Involvement of reactive oxygen species and caspase 3 activation in arsenite-induced apoptosis. $\mathrm{J}$ Cell Physiol 1998; 177:324-33.

29 Giardina C, Boulares H, Inan MS. NSAIDs and butyrate sensitize a human colorectal cancer cell line to TNF-alpha and Fas ligation: the role of reactive oxygen species. Biochim Biophys Acta 1999; 1448:425-38.

30 Ma DC, Sun YH, Chang KZ, et al. Selective induction of apoptosis of NB4 cells from $\mathrm{G} 2+\mathrm{M}$ phase by sodium arsenite at lower doses. Eur J Haematol 1998; 61:27-35.

31 Smith JA, Weidemann MJ. Further characterization of the neutrophil oxidative burst by flow cytometry. J Immunol Methods 1993; 162:261-8.

32 Toba K, Winton EF, Koike T, Shibata A. Simultaneous threecolor analysis of the surface phenotype and DNA-RNA quantatation using 7-amino-actinomycin $\mathrm{D}$ and pyronin $\mathrm{Y}$. J Immunol Methods 1995; 182:193-207.

33 Gavrieli Y, Sherman Y, Ben-Sasson SA. Identification of programmed cell death in situ via specific labeling of nuclear DNA fragmentation. J Cell Biol 1992; 119:493-501.

34 Shi MM, Kugelman A, Iwamoto T, Tian L, Forman HJ. Quinoneinduced oxidative stress elevates glutathione and induces gammaglutamylcysteine synthetase activity in rat lung epithelial L2 cells. J Biol Chem 1994; 269:26512-7.

35. Gorczyca W, Gong J, Ardelt B Traganos F, Darzynkiewicz Z. The cell cycle related differences in susceptibility of HL-60 cells to apoptosis induced by various antitumor agents. Cancer Research 1993; 53:3186-92.

36 Donjerkovic D, Scott DW. Activation -induced cell death in B lymphocytes. Cell Research 2000; 10:179-92.

37 Allen RG and Tresini M. Oxidative Stress and Gene Regulation. Free Radic Biol 2000; 28:463-99.

38 Cai X, Shen YL, Zhu Q, et al.Arsenic trioxide-induced apoptosis and differentiation are associated respectively with mitochondrial transmembrane potential collapse and retinoic acid sigaling pathway in acute promyelocytic leukemia. Leukemia 2000; 14: 262-70.

39 Desagher S, Martinou J. Mitochondria as the central control point of apoptosis. Trends in Cell Biology 2000; 10:369-77. 